\title{
A cell-free platform for rapid synthesis and testing of active oligosaccharyltransferases
}

Jennifer A. Schoborg, ${ }^{1,2 *}$ Jasmine Hershewe, ${ }^{1,2,3 *}$, Jessica C. Stark, ${ }^{1,2}$ Weston Kightlinger, ${ }^{1,2}$ James E. Kath, ${ }^{1,2}$ Thapakorn Jaroentomeechai, ${ }^{4}$ Aravind Natarajan, ${ }^{5}$ Matthew P. DeLisa, ${ }^{4,5}$ and Michael C. Jewett ${ }^{1,2,3,6,7,8}$

${ }^{1}$ Department of Chemical and Biological Engineering, Northwestern University, 2145 Sheridan Road, Evanston, IL 60208-3120, USA

${ }^{2}$ Chemistry of Life Processes Institute, 2170 Campus Drive, Evanston, IL 60208-3120, USA

${ }^{3}$ Master of Biotechnology Program, Northwestern University, 2145 Sheridan Road, Evanston, IL 60208-3120, USA

${ }^{4}$ Robert Frederick Smith School of Chemical and Biomolecular Engineering, Cornell University, Ithaca, New York 14853, USA

${ }^{5}$ Department of Microbiology, Cornell University, Ithaca, New York 14853, USA

${ }^{6}$ Member, Robert H. Lurie Comprehensive Cancer Center, Northwestern University, 676 N. St Clair St, Suite 1200, Chicago, IL 60611-3068, USA

${ }^{7}$ Simpson Querrey Institute, Northwestern University, 303 E. Superior St, Suite 11-131, Chicago, IL 60611-2875, USA

${ }^{8}$ Center for Synthetic Biology, Northwestern University, 2145 Sheridan Road, Evanston, IL 60208-3120, USA

*These authors contributed equally

Correspondence: Michael C. Jewett, 2145 Sheridan Road, Tech E-136, Evanston, IL 60208-3120, m-jewett@northwestern.edu

Keywords

cell-free protein synthesis, PgIB, synthetic biology, oligosaccharyltransferase, nanodisc, asparagine-linked protein glycosylation, membrane protein, post-translational modification 


\section{Abstract}

Protein glycosylation, or the attachment of sugar moieties (glycans) to proteins, is important for protein stability, activity, and immunogenicity. However, understanding the roles and regulations of site-specific glycosylation events remains a significant challenge due to several technological limitations. These limitations include a lack of available tools for biochemical characterization of enzymes involved in glycosylation. A particular challenge is the synthesis of oligosaccharyltransferases (OSTs), which catalyze the attachment of glycans to specific amino acid residues in target proteins. The difficulty arises from the fact that canonical OSTs are large $(>70 \mathrm{kDa})$ and possess multiple transmembrane helices, making them difficult to overexpress in living cells. Here, we address this challenge by establishing a bacterial cell-free protein synthesis platform that enables rapid production of a variety of OSTs in their active conformations. Specifically, by using lipid nanodiscs as cellular membrane mimics, we obtained yields of up to 440 $\mu \mathrm{g} / \mathrm{mL}$ for the single-subunit OST enzyme, 'Protein glycosylation B' (PglB) from Campylobacter jejuni, as well as for three additional PgIB homologs from Campylobacter coli, Campylobacter lari, and Desulfovibrio gigas. Importantly, all of these enzymes catalyzed $N$-glycosylation reactions in vitro with no purification or processing needed. Furthermore, we demonstrate the ability of cell-free synthesized OSTs to glycosylate multiple target proteins with varying $N$-glycosylation acceptor sequons. We anticipate that this broadly applicable production method will advance glycoengineering efforts by enabling preparative expression of membrane-embedded OSTs from all kingdoms of life. 


\section{Introduction}

Asparagine-linked ( $N$-linked) glycosylation is one of the most prevalent polypeptide modifications in nature and is present in all domains of life (Apweiler, Hermjakob, \& Sharon, 1999; Nothaft \& Szymanski, 2010). Glycosylation affects a multitude of protein characteristics including folding, immunogenicity, activity, half-life, and regulation of signaling cascades (Apweiler et al., 1999; Helenius \& Aebi, 2004; Varki, 1993; Walsh, 2010). Despite the importance of glycans in biology, defining the rules governing structural and functional consequences of site-specific glycosylation remains an active area of investigation. Challenges arise due to several complications associated with producing and characterizing natural glycosylation systems, however. One of the major challenges is that methods for synthesis and functional analysis of enzymes that modify and transfer glycans remain limiting, as exemplified by the small fraction of characterized enzymes (1\% of more than 250,000) in the carbohydrate-active enzymes database (http://www.cazy.org/) (Lombard, Ramulu Golaconda, Drula, Coutinho, \& Henrissat, 2014).

Oligosaccharyltransferases (OSTs) are a class of membrane-bound enzymes that contain many (up to 13) transmembrane helices. OSTs facilitate the transfer of preformed oligosaccharides en bloc from lipid-linked oligosaccharides (LLOs) to target proteins bearing an amino acid sequence, or sequon, of the form $\mathrm{N}-\mathrm{X}-\mathrm{S} / \mathrm{T}$, where $\mathrm{X}$ is any amino acid except proline. In higher eukaryotes, the OST is composed of multiple subunits with the catalytic subunit denoted as STT3, whereas known archaeal and bacterial OSTs are composed of a single subunit, typically denoted as AglB and PglB, respectively (Kelleher \& Gilmore, 2006; Maita, Nyirenda, Igura, Kamishikiryo, \& Kohda, 2010; Matsumoto et al., 2013). OSTs are effectively the "gatekeepers" of $N$-linked glycosylation because their substrate preferences determine which proteins will be glycosylated, where the glycosidic bond will be formed, and which oligosaccharide will be attached at a given site (Chen, Glover, \& Imperiali, 2007; Kowarik, Young, et al., 2006; Lizak, Gerber, Numao, Aebi, \& Locher, 2011; Ollis et al., 2015). Therefore, the ability to rapidly synthesize and characterize a wide range of OSTs would be a valuable biochemical tool that could enable a deeper understanding of these important enzymes and unlock their full biotechnological potential. Unfortunately, recombinant expression of integral membrane proteins in living cells is tedious, and is limited by issues arising from 
cell toxicity and insolubility (Jaffee \& Imperiali, 2013). Furthermore, purification and refolding of membrane proteins often requires lengthy optimization. These challenges present a unique opportunity for the application of cell-free protein synthesis (CFPS) in combination with in vitro glycosylation (IVG) systems for preparative expression and functional characterization of OSTs.

CFPS in crude lysates provides an alternative method for producing proteins that are recalcitrant to recombinant expression in vivo, with several distinct advantages (Carlson, Gan, Hodgman, \& Jewett, 2012). CFPS enables the synthesis of active protein in under a day, rapid screening of large protein libraries, and direct quantification of soluble and total yields of the target protein without cell lysis and purification. Moreover, the open reaction environment allows for precise control of reaction conditions, which is increasingly being applied to the biosynthesis of active membrane proteins. In recent years, a growing number of examples include the manufacture of ATP synthase (Matthies, Haberstock, Joos, Dotsch, \& Al., 2011), G-protein-coupled receptors (Corin et al., 2011; Kaiser et al., 2008; Proverbio et al., 2013), and human mitochondrial voltagedependent anion channel (Damiati et al., 2015). The key idea is to synthesize membrane proteins in the presence of natural or synthetic lipids and/or detergents that help solubilize the membrane protein. For example, membrane mimics such as micelles, liposomes, and nanodiscs have been used to synthesize membrane proteins in soluble, well-folded conformations (Cappuccio et al., 2008; Kubick, Gerrits, Merk, Stiege, \& Erdmann, 2009; Liguori, Marques, \& Lenormand, 2008; Matthies et al., 2011; Sachse, Dondapati, Fenz, Schmidt, \& Kubick, 2014; Schwarz et al., 2007). Additionally, detergents such as $N$-dodecyl- $\beta$-D-maltoside (DDM) and Triton $\mathrm{X}-100$ are also commonly used as additives to prevent aggregation of hydrophobic polypeptide sequences (Jaffee \& Imperiali, 2013; Klammt et al., 2004; Lyukmanova et al., 2012; Seddon, Curnow, \& Booth, 2004).

Given the emergence of efforts to synthesize membrane proteins with CFPS, we aimed to develop an Escherichia coli crude extract-based platform that combines CFPS and IVG for synthesis and characterization of OSTs (Figure 1). Although many platforms for CFPS have been used for membrane protein expression, including wheat germ (Periasamy et al., 2013), rabbit reticulocytes (Kaneda et al., 2009), and insect cells (Kubick et al., 2009; Sachse et al., 2013), the E. coli platform was chosen for three 
reasons. First, it has the highest batch protein biosynthesis yields, with up to $2.3 \mathrm{mg} / \mathrm{mL}$ reported for a model green fluorescent protein (Caschera \& Noireaux, 2014). Second, E. coli lysates lack native $N$-linked glycosylation machinery, providing a blank canvas for bottom-up glycoengineering (Valderrama-Rincon et al., 2012) as well as eliminating the possible contamination from native glycosylation machinery. Third, emerging bacterial glycoengineering efforts have recently demonstrated the potential for using bacterial systems for fundamental and applied glycobiology efforts (for recent reviews see Baker, Çelik, \& DeLisa, 2013 and Merritt, Ollis, Fisher, \& DeLisa, 2013). The functional transfer of the $N$-linked protein glycosylation cluster from Campylobacter jejuni into $E$. coli set a precedent for engineering heterologous glycosylation pathways in E. coli, and has since enabled extensive study of protein glycosylation machinery for a variety of exciting applications (Baker et al., 2013; Valderrama-Rincon et al., 2012; Wacker et al., 2002). For example, PglB homologs from a variety of microbes have been expressed in $E$. coli and shown to glycosylate non-native target proteins with non-native LLOs in vivo (Ollis et al., 2015). Importantly for this work, E. coli has also served as a chassis for studying in vitro glycosylation of CFPS-expressed acceptor proteins with purified PglBs from recombinant expression cultures (Guarino \& DeLisa, 2012).

In this work, we extend our previous approach by demonstrating that the OST can be synthesized in CFPS, rather than purified from cells. Specifically, we optimized the utilization of detergents and membrane mimics to enable rapid and efficient cell-free expression of soluble PgIB from C. jejuni (CJPglB). By testing more than 15 independent conditions, we identified conditions capable of synthesizing CjPgIB at yields of up to 440 $\mu \mathrm{g} / \mathrm{mL}$, and showed that CjPgIB can be quantitatively added to in vitro activity assays with no purification or processing necessary. Using our optimized CFPS conditions, we additionally demonstrated the generalizability of our platform to the soluble synthesis of three additional bacterial OSTs, which actively glycosylated various target proteins and sequons. Our method provides flexibility for rapidly testing OST variants, manipulating physicochemical conditions, and decoupling glycosylation activity from cell toxicity constraints (Guarino \& DeLisa, 2012). We expect that our approach will be useful for generating and assessing the activity of diverse OSTs through the use of well-defined experimental conditions. 


\section{Results}

Effects of membrane mimics on solubility and yields of $\mathrm{Cj} P g / B$

The goal of this work was to develop a CFPS platform for the expression and characterization of OSTs. As a model OST, we chose to synthesize CjPgIB because its lipid-linked oligosaccharide and amino acid sequon specificities are well-studied (Chen et al., 2007; Ollis et al., 2015). Additionally, CjPglB functions as a single subunit, making its study more tractable than multi-subunit OSTs found in higher organisms. The initial metric for success in comparing reaction conditions was high solubility of $\mathrm{CjPgIB}$ in CFPS. Total and soluble OST expression was measured by incorporating ${ }^{14} \mathrm{C}$-leucine during $15-\mu \mathrm{L}$ combined transcription-translation reactions at $30^{\circ} \mathrm{C}$. CFPS yields were measured before (total) and after (soluble) centrifugation, where the centrifugation step was used to remove insoluble product from the reaction mixture (Figure 2). To gauge the impact membrane mimics on CjPgIB solubility, we compared multiple conditions to a control reaction where no membrane mimics were present. In the control reaction, solubility of CjPglB was just $11 \%$, with $49 \pm 5 \mu \mathrm{g} / \mathrm{mL}$ soluble and $442 \pm 28 \mu \mathrm{g} / \mathrm{mL}$ total yields. This is shown in the first condition of Figure $\mathbf{2 A}$.

To increase soluble yields, CFPS reactions were supplemented with multiple membrane mimics at a range of concentrations. It is notable that these membrane mimics were supplemented at the start of the reaction to encourage proper folding of the hydrophobic domains within CjPgIB. The effects of adding non-ionic detergents to CFPS were studied first. DDM and Triton X-100 were chosen because they are commonly used in CFPS reactions (Klammt et al., 2004; Lyukmanova et al., 2012) and for extraction of membrane proteins from cellular membranes, particularly for functional assays (Jaffee \& Imperiali, 2013; Moraes, Evans, Sanchez-Weatherby, Newstead, \& Stewart, 2014; Seddon et al., 2004). Additionally, these detergents have routinely been added to IVG reactions with CjPgIB (Chen et al., 2007; Gerber et al., 2013; Guarino \& DeLisa, 2012; Lizak et al., 2013; Slynko et al., 2009). With the exception of $0.1 \%(w / v) D D M$, all conditions produced less total protein than was produced without a membrane mimic, but solubility was generally increased (Figure 2A). CjPgIB synthesized in the presence of DDM remained $95 \%$ soluble for $0.5,1$, and $2 \%(\mathrm{w} / \mathrm{v})$ detergent conditions. The highest soluble yield of the detergent conditions tested was $338 \pm 15 \mu \mathrm{g} / \mathrm{mL}$ for $0.5 \%$ (w/v) DDM and the 
best condition for Triton X-100, 1\% (v/v), yielded $244 \pm 71 \mu \mathrm{g} / \mathrm{mL}$ soluble $\mathrm{CJPglB}$ at $77.6 \%$ solubility (Figure $2 \mathrm{~A}$ ).

We next tested the effect of nanodiscs on the synthesis of soluble CJPgIB in CFPS. Nanodiscs are defined nanostructures, composed of phospholipid bilayers that are solubilized into discoidal patches by two copies of an amphipathic membrane scaffold protein (MSP) (Bayburt \& Sligar, 2010). Nanodiscs stabilize highly-hydrophobic protein domains by acting as a support for co-translational membrane association (Baumann et al., 2016; Bayburt \& Sligar, 2010; Lyukmanova et al., 2012). Nanodiscs consisting of a 1palmitoyl-2-oleoyl-sn-glycero-3-phosphocholine (POPC) lipid bilayer, encased by the MSP 1E3D1 were used. This combination led to the assembly of nanodiscs with a $12 \mathrm{~nm}$ average hydrodynamic diameter (Supplementary Figure 1) (Denisov, Grinkova, Lazarides, \& Sligar, 2004). It is notable that $12 \mathrm{~nm}$ of lipid bilayer per nanodisc provides ample space to accommodate properly-folded PglB, which has a predicted diameter of roughly $5 \mathrm{~nm}$ across (Lizak et al., 2011; Musial-Siwek, Jaffee, \& Imperiali, 2016). Mizrachi et al. have shown that fusing integral membrane proteins to MSP can be used to produce soluble, active membrane proteins (Mizrachi et al., 2015); hence, MSP in the absence of a lipid bilayer was also pursued as a potential hydrophobic shield. Both the MSPs and NDs allowed for total expression of at least $443 \pm 44 \mu \mathrm{g} / \mathrm{mL}$ CjPglB. Additionally, supplementing $1 \mathrm{mg} / \mathrm{mL}$ MSP to CFPS resulted in the product of $488 \pm 58$ $\mu \mathrm{g} / \mathrm{mL}$ soluble CjPglB; supplementing $0.5,1$, and $2 \mathrm{mg} / \mathrm{mL}$ NDs to reactions yielded 461 $\pm 22,460 \pm 15$, and $447 \pm 4 \mu \mathrm{g} / \mathrm{mL}$ soluble $C J P g l B$, respectively (Figure $2 \mathrm{~A}$ ). Further, the OST was shown to be associated with the nanodiscs through an immunoprecipitation assay (Supplementary Figure 2). Additionally, the time and temperature dependence of solubility was studied with ${ }^{14} \mathrm{C}$-leucine incorporation to optimize the incubation duration and temperature of CFPS reactions (Supplementary Figure 3).

We next tested the effectiveness of each of the membrane mimics in producing functionally active OST. Reaction products corresponding to the highest soluble conditions for each membrane mimic were added to IVG reactions as an activity assay. IVG reactions consisted of CFPS-derived CjPgIB, purified AcrA (a native C. jejuni glycoprotein that contains two glycosylation acceptor sites), and a crude membrane extract from $E$. coli cells carrying the pgl pathway, which encodes a biosynthetic gene cluster to build LLOs bearing the $C$. jejuni $N$-linked glycan. The $C$. jejuni glycan is a 
heptasaccharide with the following structure: GalNAc- $\alpha 1,4-G a l N a c-\alpha 1,4-[G \mid c \beta 1,3-$ ]GalNAc-a1,4-GalNAc- $\alpha 1,4-G a l N a c-\alpha 1,3-B a c-\beta 1$, where Bac is bacillosamine, or 2,4diacetamido-2,4,6-trideoxyglucose (Young et al., 2002). OST activity was assayed via Western blots probed with an anti-polyhistidine antibody against the polyhistidine-tagged acceptor protein, or $C$. jejuni glycan-specific serum against the glycan. CjPglB synthesized in CFPS reactions supplemented with nanodiscs exhibited glycosylation activity, as evidenced by bands in the anti-polyhistidine blot corresponding to singly glycosylated (G1) and doubly glycosylated (G2) forms of AcrA (Figure 2B; Supplementary Figure 4). Western blot analysis with anti-glycan serum further corroborated the attachment of the $C$. jejuni glycan to AcrA at either 1 or 2 sites. Specific glycosylation with the $C$. jejuni heptasaccharide at the two predicted sequons in AcrA was confirmed by liquid chromatography-tandem mass spectrometry (Supplementary Figure 5). Despite having greater than 95\% soluble expression, CjPgIB produced by CFPS in the presence of $0.5 \%$ (w/v) DDM was completely inactive (Figure 2B; Supplementary Figure 4). Likewise, the absence of a membrane mimic, 1\% (v/v) Triton $\mathrm{X}-100$, and $1 \mathrm{mg} / \mathrm{mL} \mathrm{MSP}$ also yielded inactive CJPglB enzymes (Figure 2B). Importantly, no glycosylation was observed when LLOs were omitted from reaction mixture containing active CjPglB (Figure 2B). Taken together, these data confirm that CFPS-derived CjPgIB produced in the presence of nanodiscs is active.

Having confirmed glycosylation activity, we took advantage of the open nature of CFPS and IVG reactions to optimize conditions for glycosylation efficiency and yields. By cotitrating crude LLO extract, purified acceptor protein, and CFPS reactions containing active CjPglB, we quickly identified conditions that yielded high glycosylation efficiencies of another model glycoprotein called scFv13-R4 ${ }^{\text {DQNAT }}$ (Supplementary Figure 6). The scFv13-R4 ${ }^{\text {DQNAT }}$ protein is a single-chain Fv antibody containing a single optimized $C$. jejuni glycosylation sequon (DQNAT) behind a flexible linker as a C-terminal fusion (Fisher et al., 2011; Kowarik, Numao, et al., 2006; Silverman \& Imperiali, 2016; Valderrama-Rincon et al., 2012). Under the described biochemical conditions, the highest conversion to glycosylated protein was observed when active CjPgIB was supplemented in 10-fold excess of purified scFv13-R4 ${ }^{\text {DQNAT }}$ (i.e., $2 \mu \mathrm{M}$ OST and $0.2 \mu \mathrm{M}$ purified acceptor protein). 


\section{Synthesis of active bacterial OST homologs with CFPS}

To test the generality of our platform, three additional bacterial OSTs, including PgIB homologs from Campylobacter coli (CcPglB), Campylobacter lari (C/PglB) and Desulfovibrio gigas (DgPglB), were expressed in CFPS containing $1 \mathrm{mg} / \mathrm{mL}$ nanodiscs using the optimized conditions from above. These OSTs have previously been demonstrated by Ollis et al. to glycosylate scFv13-R4 ${ }^{\text {DQNAT }}$ with the $C$. jejuni glycan in vivo (Ollis et al., 2015). Each of these OSTs was produced with approximately $100 \%$ solubility as determined by ${ }^{14} \mathrm{C}$-leucine incorporation (Figure 3 ) and the soluble yields were comparable to that achieved for CJPgIB. Specifically, we produced $439 \pm 14 \mu \mathrm{g} / \mathrm{mL}$ or $5.3 \pm 0.2 \mu \mathrm{M}$ for $\mathrm{CjPgIB}, 326 \pm 17 \mu \mathrm{g} / \mathrm{mL}$ or $4.0 \pm 0.2 \mu \mathrm{M}$ for $C \mathrm{CPglB}, 339 \pm 34 \mu \mathrm{g} / \mathrm{mL}$ or $4.0 \pm 0.4 \mu \mathrm{M}$ for $\mathrm{C} / \mathrm{PglB}$, and $369 \pm 32 \mu \mathrm{g} / \mathrm{mL}$ or $4.5 \pm 0.4 \mu \mathrm{M}$ for $\mathrm{DgPglB}$. Following soluble expression, we tested all four OSTs for their ability to glycosylate scFv13R4 ${ }^{\text {DQNAT }}$. Similarly to CjPgIB, all three OSTs were active (Figure 4A; Supplementary Figure 7), with CjPgIB and DgPglB both having glycosylation efficiencies of $>75 \%$ under the optimized IVG conditions tested.

We next set out to demonstrate how the open CFPS environment could facilitate rapid OST characterization. Specifically, we assessed sequon specificity of CFPS-derived OSTs by testing the glycosylation activity of the four bacterial OSTs with purified ScFv13$\mathrm{R} 4^{\mathrm{AQNAT}}$, which contains a single, C-terminal copy of the alternative glycosylation sequon, AQNAT (Figure 4B; Supplementary Figure 8). Because a key part of the catalytic cycle of the OST is to physically bind to the sequon before glycan transfer, simple modifications in the 5-amino acid sequon dictate the ability of the OST to exhibit glycosylation activity (e.g., modification of DQNAT to AQNAT changes the -2 sequon position and eliminates activity of the CjPgIB on an otherwise identical protein) (Lizak et al., 2011; Ollis et al., 2015). Consistent with earlier in vivo experiments (Ollis et al., 2015), only CFPS-derived DgPgIB was able to glycosylate purified scFv13-R4 ${ }^{\text {AQNAT }}$ in vitro. It is notable that when IVG reactions were run with CFPS reaction product containing no OST, model glycoproteins were not glycosylated (Figure 4). Taken together, our results demonstrate that protein glycosylation by CFPS-derived OSTs is robust, applicable to different proteins, and similar to activities displayed by their counterparts produced in vivo. 


\section{Discussion}

We present a new crude extract-based CFPS platform for the synthesis and characterization of OSTs. This platform was generated using an E. coli-based CFPS system augmented with nanodiscs to facilitate expression of four distinct, active bacterial OSTs at titers up to $440 \mu \mathrm{g} / \mathrm{ml}$. A major benefit of the platform presented here is the ability to precisely control CFPS reaction conditions to obtain active PglB at high titers, offering an alternative to in vivo expression and purification for OST expression and study. By tuning CFPS conditions, we rapidly identified several conditions where greater than $75 \%$ soluble product was synthesized (Figure 2A). This open system allowed for identification of synthesis conditions that produced active and soluble products (Figure 2B) and the ability to test a variety of glycosylation conditions to drive higher glycosylation efficiencies. Finally, this method was extended to three additional OSTs that displayed high soluble expression and activity with no additional optimization of the reaction conditions.

Notably, solubility is not sufficient for enzymatic activity of OSTs, and activity is largely dependent on the ability of the membrane mimic to support proper folding of the transmembrane regions. These observations are supported by structural studies of bacterial and archaeal OST homologs (Lizak et al., 2011; Matsumoto, Taguchi, Shimada, Igura, \& Kohda, 2017), which reveal that proper folding of transmembrane regions is crucial for activity. Specifically, several residues located between transmembrane regions are implicated in substrate recognition and the ability of an OST to act on the acceptor asparagine and lipid donor (Lizak et al., 2011). Since these residues must be precisely positioned with respect to the active site, proper folding of the hydrophobic regions is key for OST activity. OSTs produced co-translationally with detergents did not show glycosylation activity despite high solubility, and high yields of active enzyme were only achieved through CFPS supplemented with nanodiscs. We hypothesize that the phospholipid bilayer afforded by nanodiscs more closely mimics a native membrane environment than detergents do, providing the necessary lipid environment for activity. Generally, cell-free expression of membrane proteins using nanodiscs has been shown to lead to the direct incorporation of proteins into pre-formed nanodiscs, supporting our observations (Baumann et al., 2016; Denisov \& Sligar, 2017; 
Lyukmanova et al., 2012). It is notable that PglB has been produced in vivo in E. coli and extracted with detergents (such as Triton $\mathrm{X}-100$ ) while retaining activity. We hypothesize that in vivo, E. coli phospholipids support proper folding PglB, and remain associated with the enzyme through purification and detergent extraction, allowing the enzyme to remain in active conformation (Guarino \& DeLisa, 2012; Jaffee \& Imperiali, 2013). Ultimately, existing literature suggests that preferred membrane mimics vary between classes of membrane proteins and particular applications. Therefore, it is important for a synthesis platform to be compatible with a wide range of membrane mimics, as is the case in the current work.

In the future, we anticipate the use of our method for the synthesis and study of other single-subunit OSTs, especially given the speed, simplicity, and consistency of this CFPS method. An expression-based system for characterizing OSTs is needed, especially because of the significant challenges that exist in determining meaningful structure-function relationships (Maita et al., 2010). These challenges stem from the wide sequence divergence of OSTs. For example, although each of the homologs tested here are of proteobacterial origin, they differ in sequence homology from $C$. jejuni (82.7\% sequence similarity for C. coli, $57.3 \%$ for C. lari, $16 \%$ for D. gigas) (Szymanski \& Wren, 2005). Thus, the expression method developed here would be particularly valuable for characterization of OSTs which are poorly characterized or predicted by the deluge of recent microbial genomic sequencing efforts (Maita et al., 2010; Weerapana \& Imperiali, 2006). Our method bypasses issues often encountered with in vivo OST characterization by decoupling enzyme yields from activity and avoiding protein purification. For instance, in work from Ollis, et al. several of the predicted bacterial OSTs analyzed in that study were deemed inactive (Ollis et al., 2015). However, it is difficult to determine whether this was due to poor in vivo expression, or due to poor affinity of the enzymes for the given substrates. The cell-free system developed here might be able to elucidate answers to such questions.

It is also plausible to extend a CFPS-based approach to high-throughput screening of OSTs for engineering novel functions and understanding their biology. Using evolution techniques, the $C$. jejuni PgIB has already been engineered in vivo to accept the general eukaryotic $\mathrm{N}-\mathrm{X}-\mathrm{S} / \mathrm{T}$ sequon as opposed to the more stringent native $\mathrm{D} / \mathrm{E}-\mathrm{X}_{1}-\mathrm{N}-\mathrm{X}_{2}-\mathrm{S} / \mathrm{T}$ sequon (Ollis, Zhang, Fisher, \& DeLisa, 2014), to increase the enzyme's efficiency 
(Ihssen et al., 2015), and to gain structural insight (Ihssen et al., 2012). However, glycan and lipid specificities are other useful attributes that could be tailored, given sufficient throughput of expression and analysis. With these targets, one could not only engineer novel OSTs, but also begin to probe which residues confer specific activities and specificities through experiments that would be a challenge to perform in vivo due to host cell lipid, and loss of library coverage in vivo (Ihssen et al., 2012). In vitro screening technologies could complement existing in vivo evolution methods, especially if integrated with liquid handling robotics for the generation and screening of enzyme variants with high-throughput.

In summary, CFPS systems are rapidly emerging as a powerful platform to understand, harness, and expand the powerful capabilities of biological systems. A recent surge of applications in prototyping genetic circuits (Noireaux, Bar-Ziv, \& Libchaber, 2003; Takahashi et al., 2015), optimizing metabolic pathways (Dudley, Anderson, \& Jewett, 2016; Karim \& Jewett, 2016; Kay \& Jewett, 2015), enabling portable diagnostics (Pardee et al., 2016), facilitating on-demand biomolecular manufacturing (Pardee et al., 2016; Salehi et al., 2016), and producing therapeutics at the commercial scale (Yin et al., 2012). Here, we show that CFPS can also be applied to the synthesis and characterization of OSTs. Poised at the intersection of glycobiology and synthetic biology, our platform has demonstrated rapid expression of a variety of soluble, active OSTs. These properties will allow for easy adoption of this platform to deepen our understanding of OST enzymology for advancing glycobiology. 


\section{Materials and Methods}

\section{Plasmid preparation}

The open reading frames of PgIBs and acceptor proteins were subcloned into the $\mathrm{pET}$ based pJL1 vector by isothermal Gibson assembly. The Uniprot accession numbers for PglBs expressed in this study are Q9S4V7, A0A1B3X965, A0A0A8H643, and T2G1X6 for $C$. jejuni, C. coli, C. lari, and D. gigas, respectively. PglB genes were expressed with either a C-terminal FLAG-tag or an HA-tag. Acceptor proteins were tagged with a Cterminal polyhistidine tag for Western Blot analysis and purification. Plasmids were isolated for use in CFPS reactions using a maxi prep kit (Qiagen) followed by ethanol precipitation. Plasmids used for transformation were isolated for use via a miniprep kit (Zymo).

\section{Nanodisc preparation and characterization}

Nanodiscs were prepared as described in Bayburt, et al. (Bayburt \& Sligar, 2010). 1palmitoyl-2-oleoyl-sn-glycero-3-phosphocholine (POPC) was purchased from Avanti Polar Lipids. Membrane scaffold protein 1E3D1 was purchased from Sigma-Aldrich. Nanodiscs were dialyzed into $1 \times$ PBS, and stored at $-80^{\circ} \mathrm{C}$ in aliquots. Nanodiscs were then analyzed on a Superdex $10 / 300$ column at $0.5 \mathrm{~mL} / \mathrm{min}$ in phosphate-buffered saline. The column was calibrated using an SEC calibration standard ranging over 15$600 \mathrm{kDa}$ (Sigma).

\section{E. coli extract preparation}

E. coli extracts were prepared as in Kwon \& Jewett, 2015. BL21 (DE3) cells (Life Technologies) grown in $1 \mathrm{~L}$ of 2 xYTPG media in full-baffle shake flasks at $37^{\circ} \mathrm{C}$. At an $\mathrm{OD}_{600}$ of $0.4,1 \mathrm{mM}$ of IPTG was added to induce T7 RNA polymerase production. Cells were harvested at an $\mathrm{OD}_{600}$ of 4.5 . Cells were pelleted via centrifugation at $5000 \mathrm{xg}$ for $15 \mathrm{~min}$ at $4^{\circ} \mathrm{C}$, washed three times with cold $\mathrm{S} 30$ buffer $(10 \mathrm{mM}$ tris acetate, $\mathrm{pH} 8.2 ; 14$ $\mathrm{mM}$ magnesium acetate; $60 \mathrm{mM}$ potassium acetate; and $1 \mathrm{mM}$ dithiothreitol), flashfrozen with liquid nitrogen, and stored at $-80^{\circ} \mathrm{C}$. For lysis, cells were thawed on ice and resuspended in $1 \mathrm{~mL}$ of $\mathrm{S} 30$ buffer per gram cells, then lysed in an EmulsiFlex-B15 homogenizer (Avestin) in a single pass at a pressure of 22,500 psi. Cellular debris was removed by two rounds of centrifugation at $30,000 \times \mathrm{xg}$ for $30 \mathrm{~min}$ at $4^{\circ} \mathrm{C}$. The supernatant was incubated at $120 \mathrm{rpm}$ for $80 \mathrm{~min}$ at $37^{\circ} \mathrm{C}$, then centrifuged at $15,000 \times \mathrm{xg}$ for $15 \mathrm{~min}$ at 
$4^{\circ} \mathrm{C}$. The final supernatant was flash-frozen with liquid nitrogen and stored at $-80^{\circ} \mathrm{C}$ until use. This extract contained $29.5+/-0.7$ total protein as measured by a Quick-Start Bradford protein assay kit (Bio-Rad).

Cell-free protein synthesis (CFPS)

CFPS reactions were performed with a modified, oxidizing PANOx-SP system (Jewett \& Swartz, 2004; Zawada et al., 2011). $15 \mu \mathrm{L}$ reactions were performed in $1.5 \mathrm{~mL}$ microcentrifuge tubes containing: $12 \mathrm{mM}$ magnesium glutamate, $10 \mathrm{mM}$ ammonium glutamate, $130 \mathrm{mM}$ potassium glutamate, $1.2 \mathrm{mM}$ adenosine triphosphate (ATP), 0.85 $\mathrm{mM}$ guanosine triphosphate (GTP), $0.85 \mathrm{mM}$ uridine triphosphate (UTP), $0.85 \mathrm{mM}$ cytidine triphosphate (CTP), $0.034 \mathrm{mg} / \mathrm{mL}$ folinic acid, $0.171 \mathrm{mg} / \mathrm{mL}$ E. coli tRNA (Roche), $2 \mathrm{mM}$ each of 20 amino acids, $30 \mathrm{mM}$ phosphoenolpyruvate (PEP, Roche), $0.33 \mathrm{mM}$ nicotinamide adenine dinucleotide (NAD), $0.27 \mathrm{mM}$ coenzyme-A (CoA), $4 \mathrm{mM}$ oxalic acid, $1 \mathrm{mM}$ putrescine, $1.5 \mathrm{mM}$ spermidine, $57 \mathrm{mM}$ HEPES, $13.3 \mu \mathrm{g} / \mathrm{mL}$ plasmid, and $30 \%(\mathrm{v} / \mathrm{v}) \mathrm{S} 30$ extract. Membrane mimics were added as described above. These mimics included $n$-dodecyl- $\beta$-D-maltoside (DDM, Anatrace), Triton X-100, membrane scaffold protein 1E3D1, and 1-palmitoyl-2-oleoyl-sn-glycero-3-phosphocholine (POPC) nanodiscs. If not specified, the reactions contained $1 \mathrm{mg} / \mathrm{mL}$ POPC nanodiscs. Reactions were incubated for $6 \mathrm{~h}$ at $30^{\circ} \mathrm{C}$. Unless otherwise noted, reagents were purchased from Sigma-Aldrich. To quantify soluble and total protein yields, $0.50 \mu \mathrm{L}(0.05$ $\mu \mathrm{Ci}$ ) of radioactive ${ }^{14} \mathrm{C}$-Leucine was added to each $15 \mu \mathrm{L}$ CFPS reaction. After the reaction was complete, soluble proteins were separated by centrifugation at 20,000xg for $10 \mathrm{~min}$ at $4^{\circ} \mathrm{C}$. Proteins were quantified based on trichloroacetic acid (TCA)-precipitable radioactivity yields in a MicroBeta2 scintillation counter (PerkinElmer) (Calhoun \& Swartz, 2005).

\section{Lipid-linked oligosaccharide crude membrane extract preparation}

Plasmid pACYCpgIB::kan (Wacker et al., 2002) bearing the glycosylation pathway for $C$. jejuni with the pglB gene inactivated by the insertion of a kanamycin resistance cassette was transformed into $E$. coli CLM24 cells and plated on selection plates (LB, $34 \mu \mathrm{g} / \mathrm{mL}$ chloramphenicol) for synthesis of $C$. jejuni LLOs (GalNAc- $\alpha 1,4-G a l N a c-\alpha 1,4-[G \mid c \beta 1,3-$ ]GalNAc-a1,4-GalNAc- $\alpha 1,4-G a l N a c-\alpha 1,3-B a c-\beta 1-U n d P P)$. An overnight culture was started in 2xYTP media with $34 \mu \mathrm{g} / \mathrm{mL}$ chloramphenicol. One liter of 2xYTP (10 g/L yeast extract, $16 \mathrm{~g} / \mathrm{L}$ tryptone, $5 \mathrm{~g} / \mathrm{L} \mathrm{NaCl}, 7 \mathrm{~g} / \mathrm{L}$ potassium phosphate dibasic, $3 \mathrm{~g} / \mathrm{L}$ potassium 
phosphate monobasic; $\mathrm{pH}$ 7.2) and antibiotic was inoculated at $\mathrm{OD}_{600}$ of 0.08 . The strain expressed the glycosyltransferases (GTs) necessary for the synthesis of the C. jejuni lipid-linked oligosaccharide (LLO) on an undecaprenyl pyrophosphate anchor. Crude membrane extract was prepared as in Ollis et al., 2015. Briefly, cells were harvested by centrifugation, washed twice in resuspension buffer $(50 \mathrm{mM}$ Tris- $\mathrm{HCl}, 25 \mathrm{mM} \mathrm{NaOH}, \mathrm{pH}$ 7.0), and finally resuspended in $10 \mathrm{~mL}$ of resuspension buffer per $1 \mathrm{~g}$ of cell pellet. The cell suspension was then frozen in liquid nitrogen and stored at $-80^{\circ} \mathrm{C}$ overnight. Cell pellets subsequently were thawed and lysed by homogenization with an EmulsiFlex-B15 homogenizer (Avestin). The resulting extract was centrifuged twice at 15,000xg for 20 $\min$ at $4^{\circ} \mathrm{C}$ to remove unlysed cells. The supernatant was then ultra-centrifuged at $100,000 \times \mathrm{xg}$ for $1 \mathrm{~h}$ at $4^{\circ} \mathrm{C}$ to pellet the lipid fraction. The pellet was resuspended in buffer with detergent $(50 \mathrm{mM}$ Tris- $\mathrm{HCl}, 25 \mathrm{mM} \mathrm{NaCl}, 1 \%(\mathrm{v} / \mathrm{v})$ Triton X-100, pH 7.0) using a Dounce homogenizer. This suspension was incubated $1 \mathrm{~h}$ at room temperature, then centrifuged for $16,000 \mathrm{xg}$ for $1 \mathrm{~h}$ at $4^{\circ} \mathrm{C}$. The supernatant of this final spin was collected and stored at $4^{\circ} \mathrm{C}$ for in vitro glycosylation reactions.

\section{Recombinant expression and purification of acceptor proteins}

$20 \mathrm{ng}$ of plasmid DNA encoding acceptor proteins (scFv13-R4-D/AQNAT and AcrA) were transformed into BL21 Star (DE3) cells, plated on LB selection plates $(50 \mu \mathrm{g} / \mathrm{mL}$ kanamycin), and grown overnight at $37^{\circ} \mathrm{C}$. Overnight cultures were inoculated from a single colony and grown overnight in 2xYTP with kanamycin. The following day, $100 \mathrm{~mL}$ $2 x Y T P$ with kanamycin was inoculated with saturated overnight cultures to a final $O D_{600}$ of 0.08 and grown at $37^{\circ} \mathrm{C}$ until $\mathrm{OD}_{600}$ of $0.6-0.8$. Protein expression was induced with the addition of $0.5 \mathrm{mM} \mathrm{IPTG}$ and culture temperature was shifted to $30^{\circ} \mathrm{C}$. Cultures were incubated for $5 \mathrm{~h}$ before harvesting by centrifugation at 4,000xg for $15 \mathrm{~min}$. Harvested pellets were frozen in liquid nitrogen and stored at $-80^{\circ} \mathrm{C}$ for further use.

After thawing pellets for $1 \mathrm{~h}$ on ice, pellets from $100 \mathrm{~mL}$ expression cultures were resuspended in $10 \mathrm{~mL}$ of wash buffer ( $50 \mathrm{mM}$ sodium phosphate, $300 \mathrm{mM} \mathrm{NaCl}, \mathrm{pH} 8$ ) and collected at 4,000xg for $10 \mathrm{~min}$. Pellets were washed twice before lysis. After the second wash step, cells were resuspended in $10 \mathrm{~mL}$ of lysis buffer (50 mM sodium phosphate, $300 \mathrm{mM} \mathrm{NaCl}, 10 \mathrm{mM}$ imidazole, $1 \mathrm{mM}$ phenylmethanesulfonyl fluoride, $\mathrm{pH}$ 8) and lysed via high-pressure homogenization with an EmulsiFlex-B15 homogenizer (Avestin). Resuspended culture was passed through the homogenizer for a total of 4 
passes at 21,000 psi. Lysate was clarified by centrifugation at 15,000xg for $15 \mathrm{~min}$ at $4^{\circ} \mathrm{C}$. The supernatant of this centrifugation was removed, and centrifuged again at $15,000 \times$ for 15 minutes. The supernatant of the second centrifugation was removed for further purification.

Polyhistidine-tagged acceptor proteins were purified from culture supernatants using NiNTA agarose resin or Ni-NTA spin columns (Qiagen) under manufacturer's recommendations for native conditions. Resin or columns were washed with $3 x$ packed resin volumes of wash buffer containing $20 \mathrm{mM}$ imidazole, $50 \mathrm{mM}$ imidazole, followed by elution with $500 \mathrm{mM}$ imidazole. Eluted fractions were dialyzed into a storage buffer (50 mM HEPES, $500 \mathrm{mM} \mathrm{NaCl}, 1 \mathrm{mM}$ EDTA, $\mathrm{pH}$ 7) and stored at $4^{\circ} \mathrm{C}$ for subsequent use.

\section{In vitro glycosylation reactions}

Ten microliter IVG reactions containing crude PgIB expressed in CFPS, crude LLOs in E. coli membrane fraction, and purified acceptor protein were combined. CFPS reactions containing OSTs were diluted to $3.8 \mu \mathrm{M}$ OST in CFPS pre-mix. $5 \mu \mathrm{L}$ of this CFPS reaction was added to IVGs. $1 \mu \mathrm{L}$ of purified acceptor protein at $2 \mu \mathrm{M}$ in $500 \mathrm{mM} \mathrm{NaCl}$, $30 \mathrm{mM}$ Tris, and $1 \mathrm{mM}$ EDTA, pH 7 were added to IVG reactions. $1 \mu \mathrm{L}$ of a master mix (10\% (w/v) Ficoll 400, 500 mM HEPES, pH 7.4, and $100 \mathrm{mM}$ manganese chloride) was added just prior to incubation to reduce precipitation of reaction components. Reactions were then filled to volume with crude membrane extract containing LLOs. This gives the following concentrations of relevant components: $1.6 \mu \mathrm{M}$ OST, $0.2 \mu \mathrm{M}$ acceptor protein, $1 \%(\mathrm{w} / \mathrm{v})$ Ficoll 400, $50 \mathrm{mM}$ HEPES, and $10 \mathrm{mM}$ manganese chloride. Reactions were incubated overnight at $30^{\circ} \mathrm{C}$.

\section{Western blot detection of in vitro glycosylation products}

After incubation, IVG samples were centrifuged for five minutes at $20,000 \mathrm{xg}$ at $4^{\circ} \mathrm{C}$. Proteins in the supernatant were separated via SDS-PAGE on 4-12\% Bis-Tris NuPAGE gels (Invitrogen) and transferred to Immobilon PVDF membranes (Millipore) with semidry transfer using a Trans-Blot SD (Bio-Rad) for Western blot analysis. A polyclonal, HRP-conjugated anti-polyhistidine antibody from rabbit (Abcam) was used to blot against acceptor proteins. The anti-glycan serum used was a generous gift from the Aebi Lab. WesternSure ECL reagents for chemiluminescence (LI-COR) or IRDye680 and 
IRDye800 secondary antibody conjugates (LI-COR) and imaged using Odyssey FC imager (LI-COR).

\section{LC-MS/MS confirmation of presence and identity of glycosylation reaction products}

AcrA samples were prepared for LC-MS/MS analysis by in-gel digestion as follows. Nickel column purified AcrA bearing two glycosylation sites was glycosylated in IVG reactions. Six IVG reactions were run in parallel as described above, then purified by Qiagen nickel affinity spin columns according to manufacturer specifications. After purification, the glycosylated AcrA was separated on a 4-12\% SDS PAGE gel. The gel was then stained using InstantBlue (Expedeon). Gel slices containing both unglycosylated and glycosylated versions of AcrA were destained and subjected to ingel trypsin digestion as previously described (Olsen, Mann, Shevchenko, Tomas, \& Havlis, 2007) for at least $16 \mathrm{~h}$, followed by extraction of tryptic peptides.

For confirmation of the presence of $C$. jejuni glycan on AcrA glycosylation sites, AcrA tryptic peptides were analyzed using an Oribtrap Fusion (Thermo Scientific) with Ultimate LC system equipped with a custom made C18 column and nanospray Flex lon source. High-resolution MS scans and simultaneous detection of $\mathrm{N}$-acetylhexosamine (HexNAc) fragment ions $(+204 \mathrm{~m} / \mathrm{z}$ ) by MS/MS fragmentation confirmed the presence of C. jejuni glycans at both sites. For confirmation of the C. jejuni glycan identity, an identical sample of trypsin digested AcrA peptides was desalted using an Oasis HLB 96well microelution plate (Waters Corp) according to manufacturer instructions. The eluent was then concentrated to a total volume of $8 \mu \mathrm{L}$ using a Speedvac (Thermo Scientific). A $2 \mu \mathrm{L}$ sample was analyzed by LC-MS/MS using an Agilent 1290 UPLC system equipped with an ACQUITY UPLC Peptide BEH C18 Column (300Å pore size, $1.7 \mu \mathrm{m}, 2.1 \mathrm{~mm} \mathrm{X}$ $100 \mathrm{~mm}$, Waters Corp) coupled to a QTRAP 6500 mass spectrometer (AB SCIEX). MS data acquisition and analysis was carried out using Analyst software (AB SCIEX). A precursor ion scan was carried out to identify, isolate, and fragment glycopeptides containing HexNAc residues similar to previous works (Zhang et al., 2012). Briefly, the $0.1 \%(\mathrm{v} / \mathrm{v})$ formic acid $(\mathrm{FA})$ in water and acetonitrile (ACN) were used as aqueous $(\mathrm{A})$ and organic (B) solvents, respectively with a column temperature of $60^{\circ} \mathrm{C}$. A 96 minute LC gradient from $2 \%$ to $50 \% \mathrm{ACN}$ in $0.1 \% \mathrm{FA}$ at $0.2 \mathrm{~mL} / \mathrm{min}$ flow rate was used to separate glycopeptides. A precursor ion scan in positive ion mode monitoring the $\mathrm{N}$ acetylhexosamine fragment ion (+ $204 \mathrm{~m} / \mathrm{z}$ ) using a step size of $0.2 \mathrm{Da}$ was completed. 
Based on an Enhanced Resolution (ER) MS scan, Information Dependent Acquisition (IDA) triggered an MS/MS Enhanced Product lon (EPI) scan of the three highest intensity precursor ions between 400 and $2000 \mathrm{~m} / \mathrm{z}$ with charges of +2 to +5 that produced the diagnostic HexNAc fragment ion. Rolling collisional energy was used for each MS/MS scan. Acquired MS and MS/MS spectra were inspected using custom MATLAB scripts for position and composition of glycan modifications.

\section{Acknowledgements}

We thank Markus Aebi for the generous gift of the antiserum against the $C$. jejuni glycan. We acknowledge the Cornell University Biotechnology Resource Center (BRC) for data acquisition with their LC-MS/MS data acquisition. We thank the University of Illinois at Chicago and Chicago Biomedical Consortium for use of their LC-MS/MS instruments at the Mass spectrometry, Metabolomics \& Proteomics Facility. We thank Kyle Wilcox for training in the preparation of nanodiscs. JAS was supported by the National Science Foundation Graduate Research Fellowship, grant number DGE-1324585. This work was also supported by the Defense Threat Reduction Agency (GRANT11631647), the David and Lucile Packard Foundation, the Chicago Biomedical Consortium with support from the Searle Funds at the Chicago Community Trust, the Dreyfus Teacher-Scholar program, and the National Science Foundation (MCB 1413563). The authors declare that they have no conflict of interest.

\section{Author Contributions}

JAS and JMH designed, conducted, and analyzed OST synthesis and activity experiments. JCS, TJ, and AN designed and optimized experimental conditions. WK and JEK designed, performed, and interpreted mass spectrometry experiments. MCJ and MPD directed the studies and interpreted data. JAS, JMH, and MCJ wrote the paper with assistance from JCS, WK, JEK, TJ, AN, and MPD.

\section{Abbreviations}


CFPS - cell-free protein synthesis, IVG - in vitro glycosylation, LLO - lipid linked oligosaccharide, OD - optical density, OST - oligosaccharyltransferase, scFv - single chain variable fragment, ND - nanodiscs 


\section{References}

Apweiler, R., Hermjakob, H., \& Sharon, N. (1999). On the frequency of protein glycosylation, as deduced from analysis of the SWISS-PROT database. Biochim. Biophys. Acta, 1473, 4-8.

Baker, J. L., Çelik, E., \& DeLisa, M. P. (2013). Expanding the glycoengineering toolbox: the rise of bacterial $\mathrm{N}$-linked protein glycosylation. Trends in Biotechnology, 31(5), 313-23. http://doi.org/10.1016/j.tibtech.2013.03.003

Baumann, A., Kerruth, S., Fitter, J., Buldt, G., Heberle, J., Schlesinger, R., \& Ataka, K. (2016). In-situ observation of membrane protein folding during cell-free expression. PloS One, 11(3), e0151051.

Bayburt, T. H., \& Sligar, S. G. (2010). Membrane protein assembly into Nanodiscs. FEBS Letters, 584(9), 1721-7. http://doi.org/10.1016/j.febslet.2009.10.024

Calhoun, K. A., \& Swartz, J. R. (2005). An economical method for cell-free protein synthesis using glucose and nucleoside monophosphates. Biotechnol. Prog., 21(4), 1146-1153.

Cappuccio, J. A., Blanchette, C. D., Sulcheck, T. A., Arroyo, E. S., Kralj, J. M., Hinz, A. K., ... Coleman, M. A. (2008). Cell-free co-expression of functional membrane proteins and apolipoprotein, forming soluble nanolipoprotein particles. Molecular \& Cellular Proteomics, 7(11), 2246-2253. http://doi.org/10.1074/

Carlson, E. D., Gan, R., Hodgman, C. E., \& Jewett, M. C. (2012). Cell-free protein synthesis: applications come of age. Biotechnol. Adv., 30(5), 1185-1194. http://doi.org/10.1016/j.biotechadv.2011.09.016

Caschera, F., \& Noireaux, V. (2014). Synthesis of $2.3 \mathrm{mg} / \mathrm{ml}$ of protein with an all Escherichia coli cell-free transcription-translation system. Biochimie, 99, 162-8. http://doi.org/10.1016/j.biochi.2013.11.025

Chen, M. M., Glover, K. J., \& Imperiali, B. (2007). From peptide to protein: comparative analysis of the substrate specificity of $\mathrm{N}$-linked glycosylation in $\mathrm{C}$. jejuni. Biochemistry, 46(18), 5579-85. http://doi.org/10.1021/bi602633n

Corin, K., Baaske, P., Geissler, S., Wienken, C. J., Duhr, S., Braun, D., \& Zhang, S. (2011). Structure and function analyses of the purified GPCR hman vomeronasal type 1 receptor 1. Scientific Reports, 172.

Damiati, S., Zayni, S., Schrems, A., Kiene, E., Sleytr, U. B., Chopineau, J., ... Sinner, E.K. (2015). Inspired and stabilized by nature: ribosomal synthesis of the human voltage gated ion channel (VDAC) into 2D-protein-tethered lipid interfaces. Biomater Sci, 3(10), 1406-1413. http://doi.org/10.1039/C5BM00097A

Denisov, I. G., Grinkova, Y. V, Lazarides, A. A., \& Sligar, S. G. (2004). Directed selfassembly of monodisperse phospholipid bilayer Nanodiscs with controlled size. Journal of the American Chemical Society, 126(11), 3477-87. http://doi.org/10.1021/ja0393574

Denisov, I. G., \& Sligar, S. G. (2017). Nanodiscs in membrane biochemistry and biophysics. Chem Rev, 117(6), 4669-4713.

Dudley, Q. M., Anderson, K. C., \& Jewett, M. C. (2016). Cell-free mixing of Escherichia coli crude extracts to prototype and rationally engineer high-titer mevalonate 
synthesis. ACS Synth Biol, 5(12), 1578-1588.

Fisher, A. C., Haitjema, C. H., Guarino, C., Çelik, E., Endicott, C. E., Reading, C. A., ... DeLisa, M. P. (2011). Production of secretory and extracellular $\mathrm{N}$-linked glycoproteins in Escherichia coli. Applied and Environmental Microbiology, 77(3), 871-81. http://doi.org/10.1128/AEM.01901-10

Gerber, S., Lizak, C., Michaud, G., Bucher, M., Darbre, T., Aebi, M., ... Locher, K. P. (2013). Mechanism of bacterial oligosaccharyltransferase: In vitro quantification of sequon binding and catalysis. Journal of Biological Chemistry, 288(13), 8849-8861. http://doi.org/10.1074/jbc.M112.445940

Guarino, C., \& DeLisa, M. P. (2012). A prokaryote-based cell-free translation system that efficiently synthesizes glycoproteins. Glycobiology, 22(5), 596-601. http://doi.org/10.1093/glycob/cwr151

Helenius, A., \& Aebi, M. (2004). Roles of N-linked glycans in the endoplasmic reticulum. Annual Review of Biochemistry, 73, 1019-1049. http://doi.org/10.1146/annurev.biochem.73.011303.073752

Ihssen, J., Haas, J., Kowarik, M., Wiesli, L., Wacker, M., Schwede, T., \& Thöny-Meyer, L. (2015). Increased efficiency of Campylobacter jejuni N-oligosaccharyltransferase PglB by structure-guided engineering. Open Biology, 5(4), 140227. http://doi.org/10.1098/rsob.140227

Ihssen, J., Kowarik, M., Wiesli, L., Reiss, R., Wacker, M., Thöny-Meyer, L., \& Th\$\$ Meyer, L. (2012). Structural insights from random mutagenesis of Campylobacter jejuni oligosaccharyltransferase PgIB. BMC Biotechnology, 12(1), 67. http://doi.org/10.1186/1472-6750-12-67

Jaffee, M. B., \& Imperiali, B. (2013). Optimized protocol for expression and purification of membrane-bound PgIB, a bacterial oligosaccharyl transferase. Protein Expression and Purification, 89(2), 241-50. http://doi.org/10.1016/j.pep.2013.04.001

Jewett, M. C., \& Swartz, J. R. (2004). Substrate replenishment extends protein synthesis with an in vitro translation system designed to mimic the cytoplasm. Biotechnol Bioeng, 87(4), 465-472. http://doi.org/10.1002/bit.20139

Kaiser, L., Graveland-Bikker, J., Steuerwald, D., Vanberghem, M., Herlihy, K., \& Zhang, S. (2008). Efficient cell-free production of olfactory receptors: Detergent optimization, structure, and ligand binding analyses. Proc Natl Acad Sci U S A, 105(41), 15726-15731.

Kaneda, M., Nomura, S. M., Ichinose, S., Kondo, S., Nakahama, K., Akiyoshi, K., \& Morita, I. (2009). Direct formation of proteo-liposomes by in vitro synthesis and cellular cytosolic delivery with connexin-expressing liposomes. Biomaterials, 30(23), 3971-3977. http://doi.org/10.1016/j.biomaterials.2009.04.006

Karim, A. S., \& Jewett, M. C. (2016). A cell-free framework for rapid biosynthetic pathway prototyping and enzyme discovery. Metab. Eng., 36, 116-126.

Kay, J. E., \& Jewett, M. C. (2015). Lysate of engineered Escherichia coli supports highlevel conversion of glucose to 2,3-butanediol. Metab. Eng., 32, 133-142.

Kelleher, D. J., \& Gilmore, R. (2006). An evolving view of the eukaryotic oligosaccharyltransferase. Glycobiology, 16(4), 47R-62R.

http://doi.org/10.1093/glycob/cwj066 
Klammt, C., Lohr, F., Schafer, B., Haase, W., Dotsch, V., Ruterjans, H., ... Bernhard, F. (2004). High level cell-free expression and specific labeling of integral membrane proteins. Eur. J. Biochem., 271(3), 568-580. http://doi.org/10.1111/j.14321033.2003.03959.x

Kowarik, M., Numao, S., Feldman, M. F., Schulz, B. L., Callewaert, N., Kiermaier, E., ... Aebi, M. (2006). N-Linked Glycosylation of Folded Proteins by the Bacterial Oligosaccharyltransferase. Science, 314, 1148-1150.

Kowarik, M., Young, N. M., Numao, S., Schulz, B. L., Hug, I., Callewaert, N., ... Aebi, M. (2006). Definition of the bacterial N-glycosylation site consensus sequence. The EMBO Journal, 25(9), 1957-66. http://doi.org/10.1038/sj.emboj.7601087

Kubick, S., Gerrits, M., Merk, H., Stiege, W., \& Erdmann, V. A. (2009). Chapter 2 In Vitro Synthesis of Posttranslationally Modified Membrane Proteins, 63, 25-49. http://doi.org/10.1016/s1063-5823(09)63002-7

Kwon, Y.-C., \& Jewett, M. C. (2015). High-throughput preparation methods of crude extract for robust cell-free protein synthesis. Scientific Reports, 5, 8663. http://doi.org/10.1038/srep08663

Liguori, L., Marques, B., \& Lenormand, J. L. (2008). A bacterial cell-free expression system to produce membrane proteins and proteoliposomes: from cDNA to functional assay. Curr Protoc Protein Sci, Chapter 5, Unit 522.

http://doi.org/10.1002/0471140864.ps0522s54

Lizak, C., Gerber, S., Michaud, G., Schubert, M., Fan, Y.-Y., Bucher, M., ... Locher, K. P. (2013). Unexpected reactivity and mechanism of carboxamide activation in bacterial $\mathrm{N}$-linked protein glycosylation. Nature Communications, 4, 2627. http://doi.org/10.1038/ncomms3627

Lizak, C., Gerber, S., Numao, S., Aebi, M., \& Locher, K. P. (2011). X-ray structure of a bacterial oligosaccharyltransferase. Nature, 474(7351), 350-5. http://doi.org/10.1038/nature10151

Lombard, V., Ramulu Golaconda, H., Drula, E., Coutinho, P. M., \& Henrissat, B. (2014). The carbohydrate-active enzymes database (CAZy) in 2013. Nucleic Acids Res, 42(D1), D490-D495.

Lyukmanova, E. N., Shenkarev, Z. O., Khabibullina, N. F., Kopeina, G. S., Shulepko, M. A., Paramonov, A. S., ... Kirpichnikov, M. P. (2012). Lipid-protein nanodiscs for cellfree production of integral membrane proteins in a soluble and folded state: comparison with detergent micelles, bicelles and liposomes. Biochim. Biophys. Acta, 1818(3), 349-358. http://doi.org/10.1016/j.bbamem.2011.10.020

Maita, N., Nyirenda, J., Igura, M., Kamishikiryo, J., \& Kohda, D. (2010). Comparative Structural Biology of Eubacterial and Archaeal Oligosaccharyltransferases. Journal of Biological Chemistry, 285(7), 4941-4950. http://doi.org/10.1074/jbc.M109.081752

Matsumoto, S., Shimada, A., Nyirenda, J., Igura, M., Kawano, Y., \& Kohda, D. (2013). Crystal structures of an archaeal oligosaccharyltransferase provide insights into the catalytic cycle of $\mathrm{N}$-linked protein glycosylation. Proc. Natl. Acad. Sci. U.S.A., 110(44), 17868-17873. http://doi.org/10.1073/pnas.1309777110

Matsumoto, S., Taguchi, Y., Shimada, A., Igura, M., \& Kohda, D. (2017). Tethering an NGlycosylation Sequon-Containing Peptide Creates Catalytically Competent 
Oligosaccharyltransferase Complex. Biochemistry, 56(4), 602-611.

Matthies, D., Haberstock, S., Joos, F., Dotsch, V., \& Al., E. (2011). Cell-free expression and assembly of ATP synthase. J. Mol. Biol., 413(3), 593-603. http://doi.org/10.1016/j.jmb.2011.08.055

Merritt, J. H., Ollis, A. A., Fisher, A. C., \& DeLisa, M. P. (2013). Glycans-by-design: Engineering bacteria for the biosynthesis of complex glycans and glycoconjugates. Biotechnology and Bioengineering, 110(6), 1550-1564. http://doi.org/10.1002/bit.24885

Mizrachi, D., Chen, Y., Liu, J., Peng, H.-M., Ke, A., Pollack, L., ... DeLisa, M. P. (2015). Making water-soluble integral membrane proteins in vivo using an amphipathic protein fusion strategy. Nature Communications, 6, 6826. http://doi.org/10.1038/ncomms7826

Moraes, I., Evans, G., Sanchez-Weatherby, J., Newstead, S., \& Stewart, P. D. S. (2014). Membrane protein structure determination - The next generation. Biochimica et Biophysica Acta (BBA) - Biomembranes, 1838(1), 78-87. http://doi.org/10.1016/j.bbamem.2013.07.010

Musial-Siwek, M., Jaffee, M. B., \& Imperiali, B. (2016). Probing polytopic membrane protein-substrate interactions by luminescence resonance energy transfer. JACS, 138(11), 3806-3812.

Noireaux, V., Bar-Ziv, R., \& Libchaber, A. (2003). Principles of cell-free genetic circuits. Proc Natl Acad Sci U S A, 100(22), 12672-12677.

Nothaft, H., \& Szymanski, C. M. (2010). Protein glycosylation in bacteria: sweeter than ever. Nature Reviews. Microbiology, 8(11), 765-78. http://doi.org/10.1038/nrmicro2383

Ollis, A. A., Chai, Y., Natarajan, A., Perregaux, E., Jaroentomeechai, T., Guarino, C., ... DeLisa, M. P. (2015). Substitute sweeteners: diverse bacterial oligosaccharyltransferases with unique N-glycosylation site preferences. Scientific Reports, 5, 15237. http://doi.org/10.1038/srep15237

Ollis, A. A., Zhang, S., Fisher, A. C., \& DeLisa, M. P. (2014). Engineered oligosaccharyltransferases with greatly relaxed acceptor-site specificity. Nature Chemical Biology, 10(10), 816-22. http://doi.org/10.1038/nchembio.1609

Olsen, J. V, Mann, M., Shevchenko, A., Tomas, H., \& Havlis, J. (2007). In-gel digestion for mass spectrometric characterization of proteins and proteomes, 1(6), 28562860. http://doi.org/10.1038/nprot.2006.468

Pardee, K., Green, A. A., Takahashi, M. K., Braff, D., Lambert, G., Lee, J. W., ... Collins, J. J. (2016). Rapid, Low-Cost Detection of Zika Virus Using Programmable Biomolecular Components. Cell, 165(5), 1255-1266. http://doi.org/10.1016/j.cell.2016.04.059

Periasamy, A., Shadiac, N., Amalraj, A., Garajova, S., Nagarajan, Y., Waters, S., ... Hrmova, M. (2013). Cell-free protein synthesis of membrane (1,3)-beta-d-glucan (curdlan) synthase: co-translational insertion in liposomes and reconstitution in nanodiscs. Biochim. Biophys. Acta, 1828(2), 743-757. http://doi.org/10.1016/j.bbamem.2012.10.003

Proverbio, D., Roos, C., Beyermann, M., Orban, E., Dotsch, V., \& Bernhard, F. (2013). Functional properties of cell-free expressed human endothelin $A$ and endothelin $B$ 
receptors in artificial membrane environments. Biochimica et Biophysica Acta (BBA) - Biomembranes, 1828(9), 2182-2192.

Sachse, R., Dondapati, S. K., Fenz, S. F., Schmidt, T., \& Kubick, S. (2014). Membrane protein synthesis in cell-free systems: From bio-mimetic systems to biomembranes. FEBS Letters, 588(17), 2774-2781. http://doi.org/10.1016/j.febslet.2014.06.007

Sachse, R., Wüstenhagen, D., Šamalíková, M., Gerrits, M., Bier, F. F., \& Kubick, S. (2013). Synthesis of membrane proteins in eukaryotic cell-free systems. Eng. Life Sci., 13(1), 39-48. http://doi.org/10.1002/elsc.201100235

Salehi, A. S. M., Smith, M. T., Bennett, A. M., Williams, J. B., Pitt, W. G., \& Bundy, B. C. (2016). Cell-free protein synthesis of a cytotoxic cancer therapeutic: onconase production and a just-add-water cell-free system. Biotechnology Journal, 11(2), 274-281.

Schwarz, D., Junge, F., Durst, F., Frolich, N., Schneider, B., Reckel, S., ... Bernhard, F. (2007). Preparative scale expression of membrane proteins in Escherichia colibased continuous exchange cell-free systems. Nat Protoc, 2(11), 2945-2957. http://doi.org/10.1038/nprot.2007.426

Seddon, A. M., Curnow, P., \& Booth, P. J. (2004). Membrane proteins, lipids and detergents: not just a soap opera. Biochimica et Biophysica Acta, 1666(1-2), 10517. http://doi.org/10.1016/j.bbamem.2004.04.011

Silverman, J. M., \& Imperiali, B. (2016). Bacterial N-glycosylation efficiency is dependent on the structural context of target sequons. Journal of Biological Chemistry, 291(42), 22001-22010. http://doi.org/10.1074/jbc.M116.747121

Slynko, V., Schubert, M., Numao, S., Kowarik, M., Aebi, M., \& Allain, F. H. T. (2009). NMR structure determination of a segmentally labeled glycoprotein using in vitro glycosylation. Journal of the American Chemical Society, 131(3), 1274-1281. http://doi.org/10.1021/ja808682v

Szymanski, C. M., \& Wren, B. W. (2005). Protein glycosylation in bacterial mucosal pathogens. Nature Reviews Microbiology, 3(3), 225-237. http://doi.org/10.1038/nrmicro1100

Takahashi, M. K., Hayes, C. A., Chappell, J., Sun, Z. Z., Murray, R. M., Noireaux, V., \& Lucks, J. B. (2015). Characterizing and prototyping genetic networks with cell-free transcription-translation reactions. Methods, 86, 60-72. http://doi.org/10.1016/j.ymeth.2015.05.020

Valderrama-Rincon, J. D., Fisher, A. C., Merritt, J. H., Fan, Y., Reading, C. A., Chhiba, K., ... DeLisa, M. P. (2012). An engineered eukaryotic protein glycosylation pathyway in Escherichia coli. Nature Chemical Biology. http://doi.org/10.1038/nchembio.92110.1038/NCHEMBIO.921

Varki, A. (1993). Biological roles of oligosaccharides: all of the theories are correct. Glycobiology, 3(2), 97-130. http://doi.org/10.1093/glycob/3.2.97

Wacker, M., Linton, D., Hitchen, P. G., Nita-Lazar, M., Haslam, S. M., North, S. J., ... Aebi, M. (2002). N-linked glycosylation in Campylobacter jejuni and its functional transfer into E. coli. Science (New York, N.Y.), 298(5599), 1790-3. http://doi.org/10.1126/science.298.5599.1790

Walsh, G. (2010). Post-translational modifications of protein biopharmaceuticals. Drug 
Discovery Today, 15(17-18), 773-80. http://doi.org/10.1016/j.drudis.2010.06.009

Weerapana, E., \& Imperiali, B. (2006). Asparagine-linked protein glycosylation: from eukaryotic to prokaryotic systems. Glycobiology, 16(6), 91R-101R. http://doi.org/10.1093/glycob/cwj099

Yin, G., Garces, E. D., Yang, J., Zhang, J., Tran, C., Steiner, A. R., ... Murray, C. J. (2012). Aglycosylated antibodies and antibody fragments produced in a scalable in vitro transcription-translation system. $m A b s, 4(2), 217-225$.

http://doi.org/10.4161/mabs.4.2.19202

Young, N. M., Brisson, J. R., Kelly, J., Watson, D. C., Tessier, L., Lanthier, P. H., ... Szymanski, C. M. (2002). Structure of the N-linked glycan present on multiple glycoproteins in the gram-negative bacterium, Campylobacter jejuni. Journal of Biological Chemistry, 277(45), 42530-42539. http://doi.org/10.1074/jbc.M206114200

Zawada, J. F., Yin, G., Steiner, A. R., Yang, J., Naresh, A., Roy, S. M., ... Murray, C. J. (2011). Microscale to manufacturing scale-up of cell-free cytokine production--a new approach for shortening protein production development timelines. Biotechnol Bioeng, 108(7), 1570-1578. http://doi.org/10.1002/bit.23103

Zhang, S., Sherwood, R. W., Yang, Y., Fish, T., Chen, W., James, A., ... Thannhauser, T. W. (2012). Comparative Characterization of the Glycosylation Profiles of an Influenza Hemagglutinin Produced in Plant and Insect Hosts. Proteomics, 12(8), 1269-1288. http://doi.org/10.1002/pmic.201100474.Comparative 


\section{Figure Captions}

Figure 1: CFPS with membrane mimics allows expression of OSTs that are active in vitro. OSTs are first expressed in CFPS reactions containing membrane mimics. The synthesized OSTs can then be transferred directly to an IVG reaction containing LLOs and purified acceptor proteins. A key feature of this system is that LLOs and OSTs are derived from crude $E$. coli preparations, with no need for extensive purifications.

Figure 2: Soluble expression of active CjPgIB in CFPS reactions. (A) Total (white) and soluble (black) yields of $\mathrm{PgIB}$ as measured by ${ }^{14} \mathrm{C}$-leucine incorporation supplemented with DDM, Triton X-100, MSP, and POPC nanodiscs (ND). 15- $\mu \mathrm{L}$ CFPS reactions were incubated at $30^{\circ} \mathrm{C}$ for $6 \mathrm{~h}$. Values represent the means and the error bars represent the standard deviations of three independent experiments. Asterisks indicate the conditions chosen for testing activity in an IVG reaction in (B). (B) CFPS-derived CJPgIB was tested for activity in IVG reactions at $30^{\circ} \mathrm{C}$ overnight. CJPgIB at $0.65 \mu \mathrm{M}$ was incubated with AcrA at $4.05 \mu \mathrm{M}$, and LLOs at 45\% (v/v) from E. coli + pACYCpglB::kan membrane fractions. Blots were probed with anti-polyhistidine antibody and anti-glycan serum; activity is demonstrated by the appearance of singly (g1) and doubly (g2) glycosylated AcrA, which is confirmed by the anti-glycan blot. Full blots are shown in Supplementary Figure 4.

Figure 3: CFPS with nanodiscs yields soluble expression of four bacterial OSTs. Total (white) and soluble (black) yields of PglB homologs as measured by ${ }^{14} \mathrm{C}$-leucine incorporation. 15- $\mu$ l CFPS reactions were incubated at $30^{\circ} \mathrm{C}$ for $6 \mathrm{~h}$. Values represent the means and the error bars represent the standard deviations of six independent experiments.

Figure 4: IVG of acceptor proteins with all four bacterial OSTs. CFPS-derived CjPgIB (Cj), CcPglB (Cc), C/PgIB (Cl), and DgPglB (Dg) were tested for activity in IVG reactions containing purified $(\mathrm{A})$ scFv13-R4 ${ }^{\text {DQNAT }}$ or $(\mathrm{B}) \mathrm{scFv13-R4^{ \textrm {AQNAT } }}$ as acceptor proteins. Blots were probed with anti-polyhistidine antibody and anti-glycan serum. Full blots are shown in Supplementary Figures 7-8. 

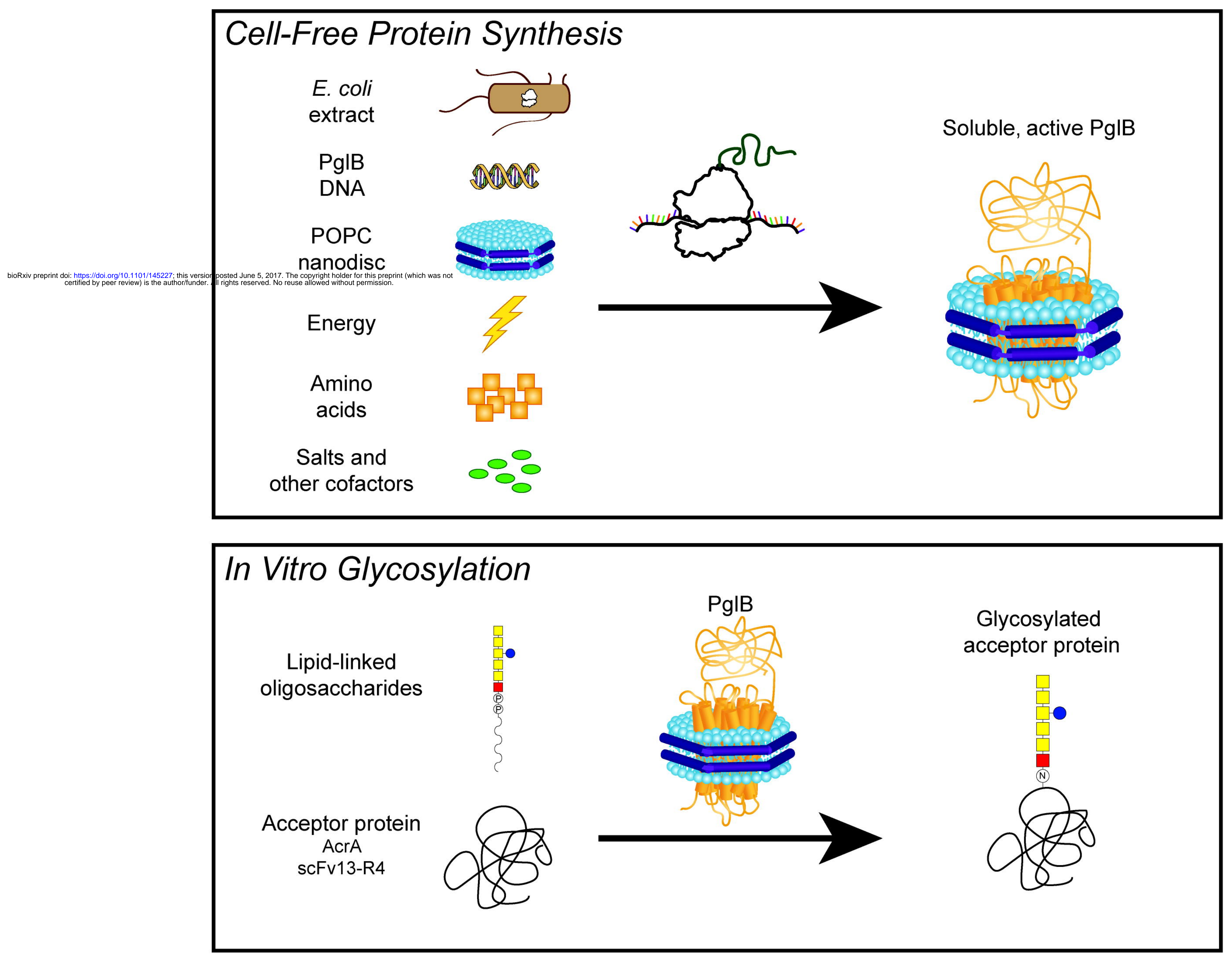


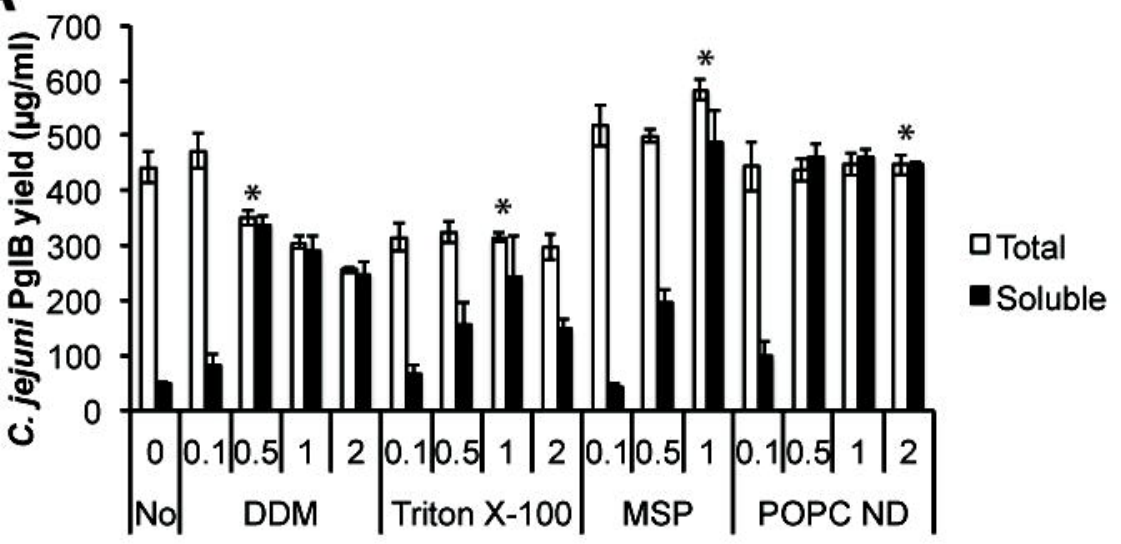

Mimic ladder ND ND none DDM Triton MSP ND

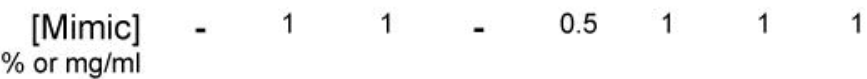

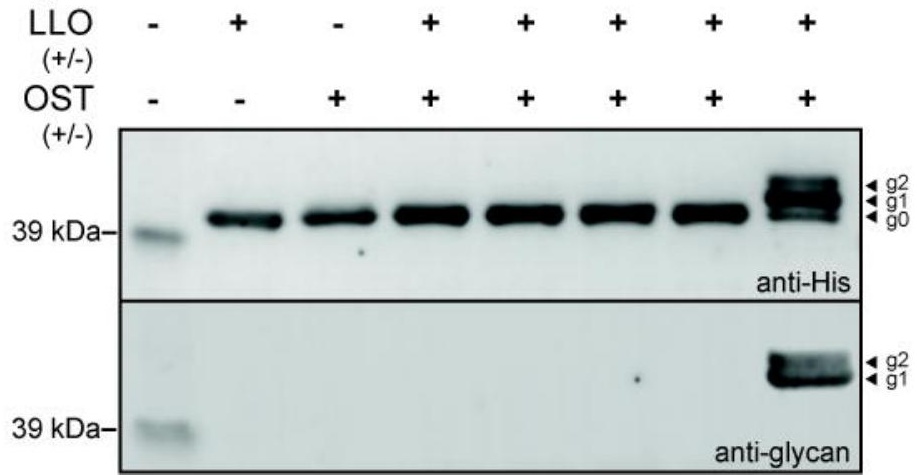




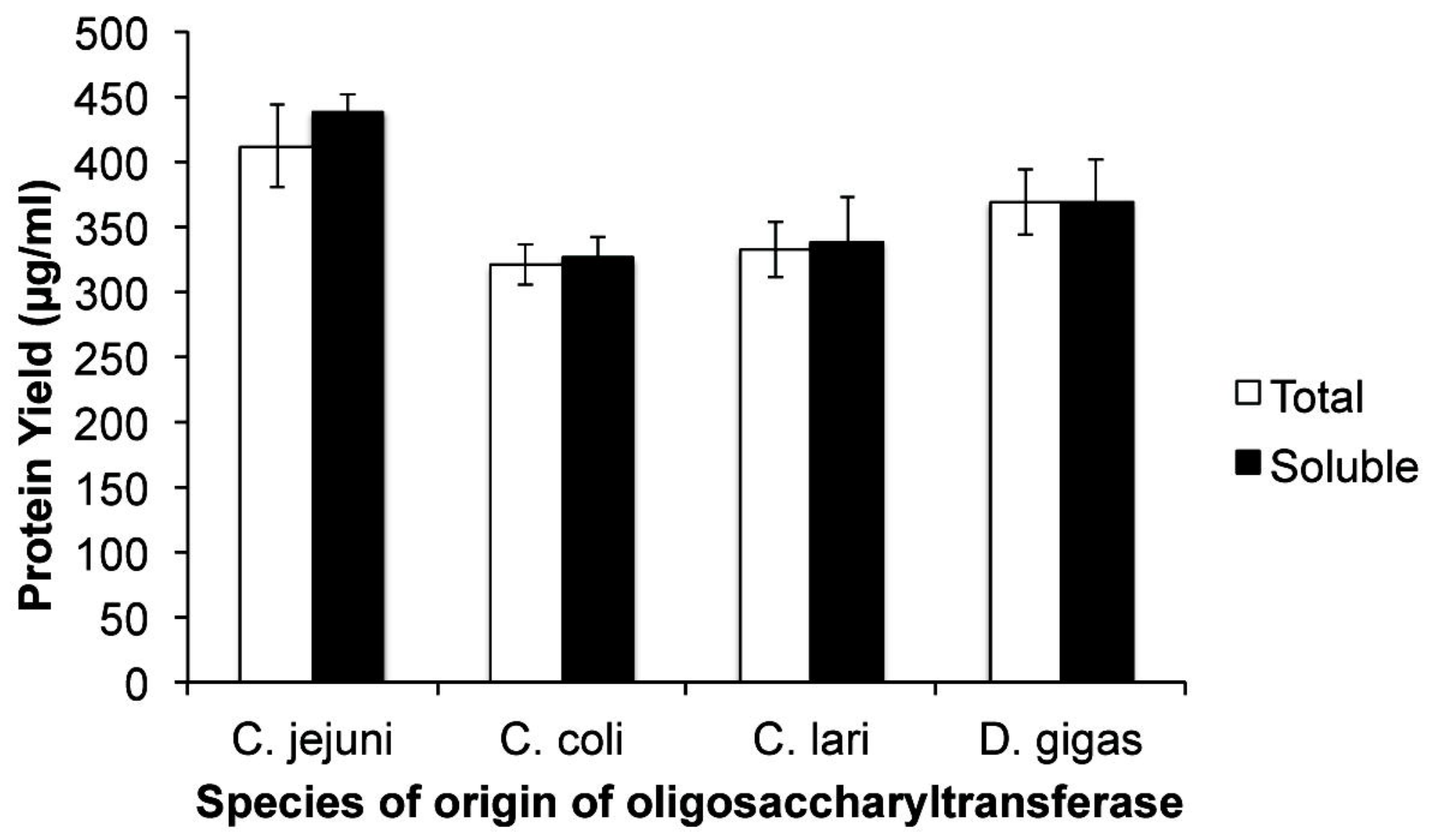


OST none $\mathrm{Cj} \quad \mathrm{Cc} \quad \mathrm{Cl} \quad \mathrm{Dg}$

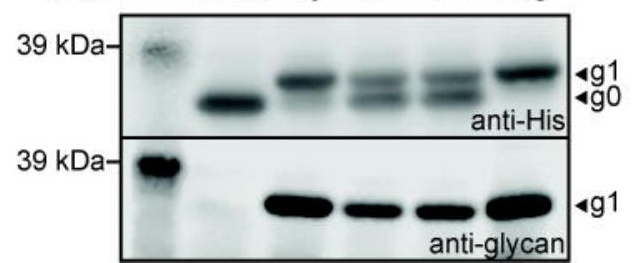

OST none $\mathrm{Cj} \quad \mathrm{Cc} \quad \mathrm{Cl} \quad \mathrm{Dg}$

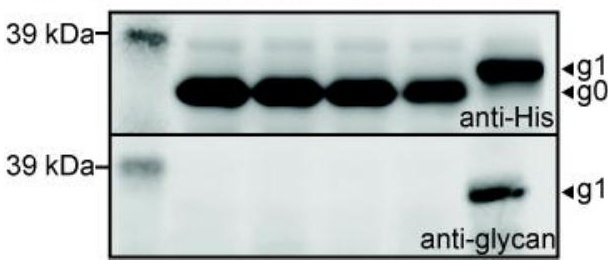

